\title{
A summary of lithology and structure within the Agto map sheet (67 V.1 Nord), Nagssugtoqidian mobile belt, West Greenland
}

\author{
Niels Ø. Olesen, John A. Korstgård and Kai Sørensen
}

Geological mapping within the Agto map sheet began in 1966 and continued to 1969 under the supervision of Bondesen $(1966,1970 \mathrm{a}, \mathrm{b})$. In this period about half the map sheet was completed. Work on the remaining part of the map sheet was resumed in 1975 and mapping was completed in 1978 (Olesen \& Sørensen, 1976; Korstgård \& Olesen, 1978). This note gives a summary of rock types and structures encountered during the mapping and fig. 1 presents the major geological features of the map sheet. A fuller description will be published together with the map.

The lithologies are remarkably similar across the map sheet and include the following major rock types:

(a) orthopyroxene-biotite \pm hornblende gneiss, mostly of tonalitic composition,

(b) biotite \pm hornblende \pm garnet gneiss, ranging from tonalitic to granitic composition,

(c) hornblende-biotite gneiss, mostly of (quartz) dioritic composition,

(d) garnet-biotite-sillimanite \pm graphite schist, mostly heterogeneously banded,

(e) biotite-graphite \pm orthopyroxene schist, mostly intimately associated with (d),

(f) marble and associated calc-sillicate rocks,

(g) quartzitic and leucocratic biotite \pm graphite \pm cordierite \pm garnet \pm sillimanite \pm clinopyroxene gneiss,

(h) \pm garnet \pm orthopyroxene \pm clinopyroxene amphibolite, and

(i) ultramafic rocks, ranging from hornblendites to pyroxenites and peridotites.

These are the country rocks into which intruded:

(j) sheets of mostly granitic to charnockitic rocks, partly developed as augen gneisses,

(k) metadolerites, ranging from discordant and undeformed to concordant and schistose,

(l) pegmatites, ranging from discordant and undeformed to concordant and strongly deformed leucocratic, gneissic rocks.

The rocks (d) to (i) mostly occur spatially associated and are believed to have originated as sedimentary and possibly extrusive rocks. Contact relations to the rocks (a) to (c) are everywhere concordant and commonly gradational. A chemical study (Korstgård, 1978) of rocks of types (a) and (b) indicates that these rocks have been through an event of melting.

A chemical study of rocks $(j)$ led Hansen (1977, this volume) to the conclusion that they form a rock suite of anorthosite kindred, generated by incomplete fractional crystallization under fairly dry conditions.

Variations in structural style permit division of the map sheet into two types of macro 


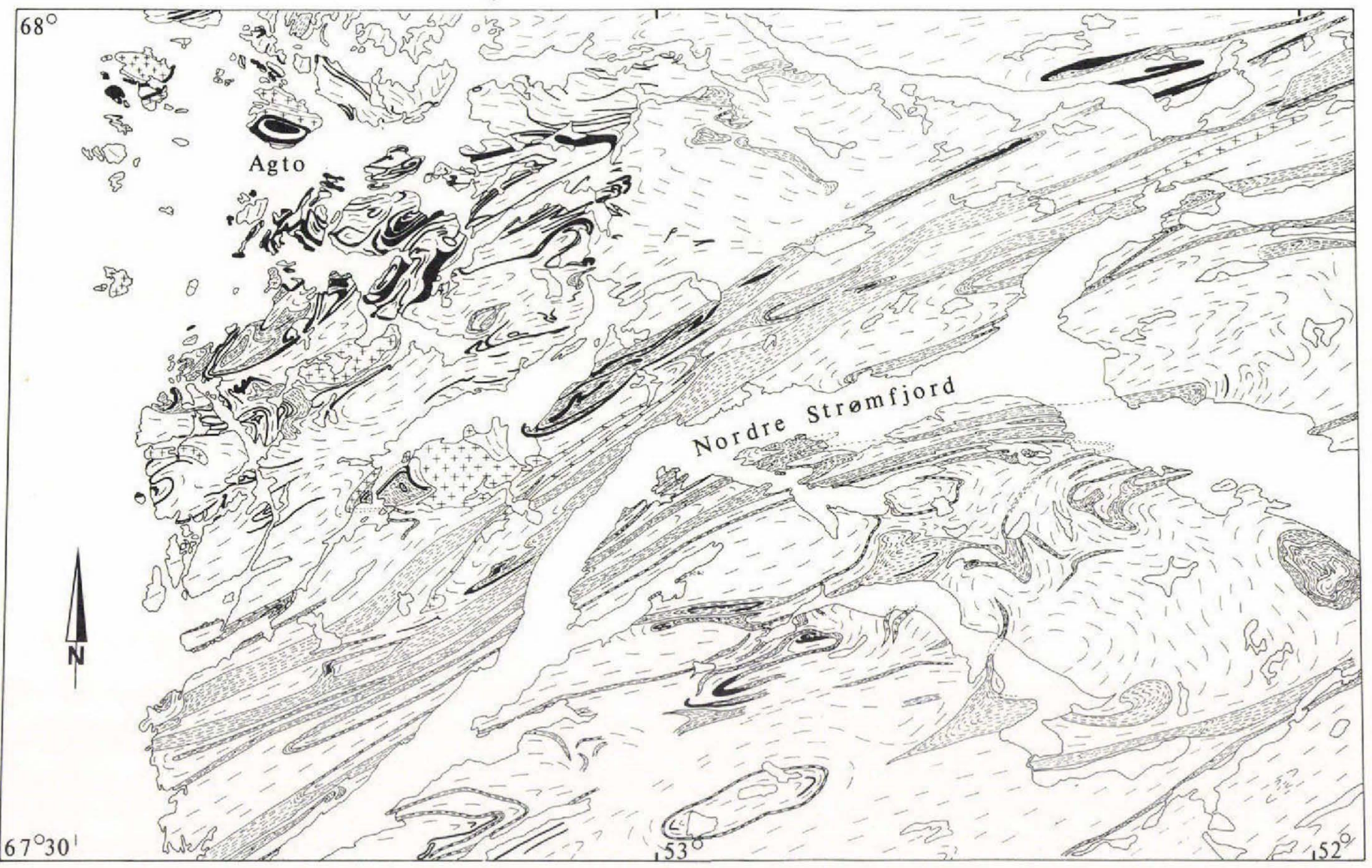

Fig. 1. Simplified geological map of the Agto sheet (67 V.1 Nord). Black: mainly amphibolites; closely spaced strike lines: various types of aluminous metasediments including marbles; widely spaced strike lines: quartzo-feldspathic gneisses of granitic to tonalitic composition; crosses: granitic and charnockitic intrusives. 
domains: (1) areas dominated by large-scale and complex fold-interference structures with highly varying axial directions, an example of which is described by Sørensen (1970), and (2) areas characterized by small variations in the orientation of layering, fold-axes, axial planes as well as in a commonly well developed planar and linear fabric, defined by a preferred habit orientation of mineral aggregates and minerals such as biotite, hornblende, orthopyroxene, sillimanite and graphite. The planar structural elements of type 2 domains mostly strike between $\mathrm{E}$ and NE and dip steeply, while the linear structural elements mostly have a shallow plunge (e.g. Korstgård, 1972; Winter, 1971).

Type 2 domains are known as 'straight belts'. There are two generations of these: an earlier generation of discontinuous nature and with trends between E-W and NE-SW, and a later generation represented by the Nordre Strømfjord Shear Zone. This zone runs diagonally across the map sheet. Its northern boundary is clearly marked in the field by sudden changes in orientation and structural style of the rocks. Of its southern boundary only the SW part is clearly recognisable in the field, but elsewhere, where the Nordre Strømfjord Shear Zone is in contact with earlier shear belts, this boundary can only be identified after inspection of geological maps and aerial photographs. A microstructural study led Olsen (1978) to suggest that stress level and strain rates were different during the formation of the two generations of 'straight belts', the older being deformed in a 'steady state creep', and the younger Nordre Strømfjord Shear Zone in a 'hot working' (cyclic recrystallization) type of deformation.

Orthopyroxene is found in rocks throughout the map sheet. Granulite facies metamorphic conditions evidently prevailed during the formation of the 'straight belts', as demonstrated by strong preferred habit and crystallographic orientation of orthopyroxene in rocks of these belts.

The intrusive rocks $(\mathrm{j})$ and $(\mathrm{k})$ postdate a planar fabric and an associated metamorphic layering, but are clearly deformed together with most other rocks in the Nordre Strømfjord Shear Zone. The only exceptions are some pegmatites and a few decimetre-wide lamprophyres.

\section{References}

Bak, J., Korstgård, J. \& Sørensen, K. 1975: A major shear zone within the Nagssugtoqidian of West Greenland. Tectonophysics 27, 191-209.

Bondesen, E. 1965: Research on the high-metamorphic complexes of the Agto area. Rapp. Grønlands geol. Unders. 11, 19-21.

Bondesen, E. 1970a: Field work in the Agto-Nordre Strømfjord region. Rapp. Grønlands geol. Unders. 28, 17-19.

Bondesen, E. 1970b: Colloquium on Nagssugtoqidian geology. Geological Institute, Aarhus University, $92 \mathrm{pp}$.

Hansen, B. 1977: En charnockitisk suite i Agto området, Vestgrønland. Unpublished cand. scient. thesis. Aarhus University.

Hansen, B. 1979: Some charnockitic rocks in the Nagssugtoqidian of West Greenland. Rapp. Grønlands geol. Unders. 89 (this volume).

Korstgård, J. A. 1972: Grundfjeldsgeologi i Inugsuk-området. Unpublished cand. scient. thesis. Aarhus University.

Korstgård, J. A. 1978: Petrography and geochemistry of Nagssugtoqidian granulite-facies gneisses from 
the Inugsuk area, Nordre Strømfjord region, West Greenland. Unpublished lic. scient. thesis. Aarhus University.

Korstgård, J. A. \& Olesen, N. Ø. 1978: Field work on the Precambrian of the Agto-Nordre Strømfjord area, central West Greenland. Rapp. Grønlands geol. Unders. 90, 36-38.

Olesen, N. Ø. \& Sørensen, K. 1976: Studies of the Precambrian basement in the Agto-Nordre Strømfjord area, central West Greenland. Rapp. Grønlands geol. Unders. 80, 68-69.

Olsen, T. S. 1978: Prækambrisk grundfjeldsgeologi i Qeqertaussaq W-området ved Nordre Strømfjord, den centrale del af de vest-grønlandske Nagssugtoqider. Unpublished cand. scient. thesis. Aarhus University.

Sørensen, K. 1970: Some observations on the structural and metamorphic chronology on Agto and surrounding islands, central West Greenland. Rapp. Grønlands geol. Unders. 27, $32 \mathrm{pp}$.

Winter, J. 1971: Geologisk beskrivelse af Tungarnit Nunât området, Vestgrønland, samt en kemisk undersøgelse af en bjergart fra området. Unpublished cand. scient. thesis. Aarhus University.

Geologisk Institut,

Aarhus Universitet,

8000 Århus C,

Denmark. 